\title{
perifèria
}

Number 6, June 2007

www.periferia.name

\section{Europe and its Other (i.e. The Balkans)}

\author{
Božidar Jezernik. Faculty of Arts, University of Ljubljana ${ }^{1}$
}

\section{Resumen}

A pesar que la denominación "Balcanes" parece hacer referencia a una zona geográfica, en realidad esta cadena montañosa no representa ni determina la variedad de territorios, pueblos y culturas que han sido incluidos en esta denominación a lo largo de la historia. A través de un estudio de los libros de viajes a la zona, se identifican las diferentes denominaciones y la construcción de un área ideal que representa la otra Europa, la Europa que recoge la dominación otomana.

\begin{abstract}
Although the label "Balkans" seems to be applied to a geographical area, in fact these Mountains do not represent neither the wide variety of territories of the Peninsula nor the peoples and cultures referred with this word. Through the study of the voyagers diaries to the area (among other historical sources), it is shown the different words used and that the label "Balkans" refers mainly to the "Other" Europe, the Europe under the ottoman rule.
\end{abstract}

For centuries the Balkan Peninsula had no name. Only in 1808 did the German geographer August Zeune give it the name of Hämushalbinsel, which he subsequently changed to the Balkan Peninsula, following the usual practice of naming a region after a prominent mountain range. Zeune's choice was rather arbitrary, however, as the Balkan Mountains, formerly called the Haemus (from haima, blood of Typhon), in what is now Bulgaria and known as Stara Planina (Old Mountain), constitute neither the most extensive nor the highest mountain system in the peninsula (Cf. Eremiten 1839: I, 95; Boué 1840: I, 4). In English, the name 'The Great Balcan' was first used instead of the Haemus by Frederick Calvert (1767: 139). However, almost from the beginning, the new name was considered an unworthy match of its predecessor. John Morritt, for instance, remarked in his journal in the 1790s: 'We slept at the foot of a mountain [the Shipka Pass], which we crossed the next day, which separates Bulgaria from Romania (the ancient

\footnotetext{
${ }^{1}$ email: bozidar.jezernik@ff.uni-lj.si
} 


\section{perifèria}

Number 6, June 2007

www.periferia.name

Thrace), and which, though now debased by the name of Bal. Kan, is no less a personage than the ancient Haemus' (Morritt 1914: 65).

Moreover, it appears, the name itself was the result of a misunderstanding. The Turkish noun balkan, which denotes a rugged and thickly wooded mountain or mountain chain, was assumed to be the name of this specific range (Hugonnet 1886: 25-6; Cvijić 1906: 3-4; see also Boué 1840 I, 90-7; Barth 1864: 23, 117; Braun-Wiesbaden 1878: III, 229-30). During the nineteenth century, this tautological title was imposed on the area to meet the need for a short-hand label for the new states that emerged in the territory previously known as European Turkey or Turkey-in-Europe. Arguably, the choice was at least partly due to the fact that in the first half of the nineteenth century the mountain range became famous as the theatre of the Russo-Turkish wars and, till 1877, this natural bulwark formed the second and most important line of Istanbul. Thus, a British surgeon in the Ottoman army in the middle of the nineteenth century understood Balkans to signify 'mountains of defence' (Noyes 1858: 348).

In the absence of any obvious border between the peninsula and the rest of Europe, authors have often disagreed about the exact extent of the Balkans, rendering the geography of the peninsula a very inexact science. For one thing, its area has not been stable and constant but has expanded and contracted in step with shifting political boundaries. For instance, in 1911 the Encyclopaedia Britannica defined the Balkans as encompassing 'Albania, Bosnia and Herzegovina, Bulgaria, Croatia-Slavonia, Dobrudja, Greece, Illyria, Macedonia, Montenegro, Novibazar, Servia and Turkey.' During the twentieth century this definition underwent several changes. Eventually, the 1995 edition of the Encyclopaedia Britannica Macropaedia included not only Romania and Vojvodina but also Moldova and Slovenia among the Balkan states but excluded Greece. The Balkans' place in the topography of Western imagery was illustrated most precisely by a German author, who described it as a garden shed standing beside the noble West European villa and housing many people who were unable to get on with each other and quarrelled incessantly among themselves (Ruland 1967: 27). 


\section{perifèria}

Number 6, June 2007

www.periferia.name

Agreement about the precise extent of the Balkans may have been lacking, but there has never been much disagreement about its non-European character or its intention to Europeanise itself: both were always taken for granted (Scopetea 1991: 201). After the Age of Enlightenment, the Balkans was perceived as at once near (geographically) and far (culturally). Thomas Arnold, the headmaster of Rugby School and author of History of Rome, for instance, described the eastern coast of the Adriatic as 'one of those ill-fated portions of the earth which, though placed in immediate contact with civilization, have remained perpetually barbarian' (Arnold 1838: 492). Accordingly, in Western narrations of the area those qualities that made it different from the rest of Europe were quite often deliberately stressed and many travel reports were presented as journeys back in time, away from 'the eager, restless, hurried life of Western civilization' to 'the dreamy East' (Walker 1897: 252). If the facts did not measure up to expectations, they could be changed or, if that was not feasible, disguised as picturesque and colourful survivals of the past.

If geographical terms are conventionally neutral, then the Balkans has been a notorious exception to this rule. Whenever the term is used to denote something more than a range of mountains in Bulgaria, a distinct ideological bias is introduced, with the negative connotations of filth, passivity, untrustworthiness, disregard for women, conspiracy, unscrupulousness, opportunism, indolence, superstition, sluggishness, unprincipled and overzealous bureaucracy, and so on, and so on. In the Balkan languages themselves, the term Balkan soon became a synonym for lack of civilisation and for backwardness.

'The Balkans,' then, evoked not so much a specific area as the idea of localised chaos, of balkanisation, of primitive quarrels and primeval ways of resolving them. Reverend Robert Walsh pointed out that in Western Europe 'humanity has tempered even the usages of war,' but it was not so in those countries 'and the Greeks, even at the most polished period of their history, perpetrated the greatest cruelties both on each other and on strangers, and always expected and suffered a similar retaliation' (Walsh 1836: I, 141). No wonder that polite and good-natured people thought it rude to say Balkans in the presence of a pacifist (Angell 1912: 


\section{perifèria}

Number 6, June 2007

www.periferia.name

26).

(Western) Europeans had for centuries differentiated between members of 'civilised society' on the one hand and 'primitives,' 'barbarians' and 'savages' on the other, in order to define themselves as civilised people. For this they needed their opposite, their Other, and the Balkan people served this purpose excellently. It is in fact hard to imagine a more sharply defined Other than the Balkan people. It was as if they represented, in an extravagant and colourful way, everything that had been rejected by the West generations before. Conversely, they also embodied a combination that Julia Kristeva (1991: 201) has called 'the disturbingly strange,' 'the otherness of our ourness,' which we do not know how to handle. In other words, they represented what Europeans had been but were no longer allowed to be. When during the nineteenth and twentieth centuries, hundreds and hundreds of Western travellers crisscrossed the Balkans in every direction, a lot of them actually did not see it for itself. The land and its people merely served as a kind of mirror in which they saw themselves and noticed, first and foremost, how advanced and civilised they were. In this respect, we can argue that there can be no Europe without the Balkans.

The centuries of Ottoman occupation left an imprint not just on the history of the Balkans but also on the people and their culture, and this was probably most clearly visible in the appearance of Balkan towns. Sir Edwin Pears wrote:

Under the Turkish rule, Constantinople has become the most retrograde capital in Europe. Under such rule, Athens, Bucharest, Belgrade, and Sofia, eighty years ago, were mere collections of mud huts, occupied by dejected and poverty-stricken people. Since their inhabitants got rid of Turkish oppression these villages have rapidly grown into towns, have adopted the appliances of civilization, and are all making good progress. The first two, which have enjoyed freedom for a longer time than the others, are now wellbuilt and well-governed cities with bright, intelligent, and progressive populations, and Sofia will soon run them close. To pass from any of these 


\section{perifèria}

Number 6, June 2007

www.periferia.name

towns to Constantinople is to pass from a civilized to a barbarous city (cit.

Villari 1905: 33-4).

When Captain Henry Austell visited Istanbul in 1586, he found that the great and most stately Citie of Constantinople,' with its superb location and great and sumptuous mosques, was 'to be preferred before all the Cities of Europe' (Austell 1810: 320).

However, this perspective soon changed. When, early in the seventeenth century, the English poet George Sandys visited the Levant, he found its aspect very promising from afar, but his expectations were much deceived when he entered the city (Sandys 1615: 36). After that period, to Western eyes, most Ottoman towns in the Balkans appeared more or less unattractive, despite having a certain charm when first seen from afar, the mosques, minarets and numerous domes intermingling with cypresses and fruit trees to create a fabulous spectacle (see e.g. Clarke 1810: I, 691; Greg 1833: 28; Spencer 1851: II, 371-72; Knighton 1854: 110; Gil'ferding 1859: 311; Jeran 1872: 356; De Windt 1907: 63, 216; Fox 1915: 90). When distance had ceased to lend enchantment to the view, most travellers were almost as disappointed at the close-up view as they were delighted with the long shot of Istanbul, the 'Queen of Cities' (Mrs Pardoe 1837: I, 1; A Lady 1847: 173; Leech 1869: 37; Bartlett 1897: 325; Douglas 1919: 18; Neave 1949: 11). In the mid-nineteenth century, Théophile Gautier, for instance, explained to his readers that the lovely mirage which had enwrapped the city when seen from the sea rapidly disappeared upon entering it. 'The Paradise was changed into a cloacae,' he avows (Gautier 1853: 76).

As for 'squalid architecture and filthy dressing,' in the eyes of Western travellers 'all Turkish towns were similar' (James 1913: 184).

This point of view underwent a substantial change only at the beginning of the twentieth century. The towns still looked as though nothing was finished and nothing repaired, but the perspective altered: 'A Turkish town in Europe is a Byzantine town; that is to say, it is a scene from the Middle Ages magically preserved to our own days. We are in Fairyland, we are in The Arabian Nights, and 


\section{perifèria}

Number 6, June 2007

www.periferia.name

the wicked djinn has cast a spell upon the land. Let us walk on tiptoe, lest we disturb the enchanted slumber of the Sleeping Beauty of the Wood' (Upward 1908: 185).

Not only the external appearance but also the interior of houses all over European Turkey was arranged in the Eastern style, without tables or chairs, without fork and knives, and without mirrors or painted images on the walls. The only decoration might be one or two yaftes (illuminated texts).

Balkan cities and towns seemed even more dreary to Western travellers in the nineteenth century for their lack of such urban institutions as museums and theatres, parks and pleasure gardens. There were neither promenades nor 'society' in the European sense; there were only all-male coffee houses. The idea of the seclusion of women survived until the Second World War in the sense that women had to cover their faces when they went out and were not allowed to frequent places of entertainment; this rendered Balkan society 'dull and uniform.' Education was available only to men; a woman skilled in reading and writing was spoken of as a prodigy. The focus of social life was the coffee house, where men of leisure assembled to drink coffee and smoke tobacco. The only exception was the capital of Romania, which, in the first half of the nineteenth century, became notorious as 'the Mecca of pleasure lovers' (The Man 1916: 43), on account of its women's reputation being 'as bad as that of Venetians' (Alexander 1827: 253).

This short survey of Balkan towns clearly shows that their importance has little to do with their achievements in town planning or architecture. It lies more in their production of an environment in which the spirit of the age was manifested. There is no history without a place, and no place without a history. All towns have a history and some of them have a mythology; Balkans towns have histories and mythologies which are often deliberately interwoven. As Peter Ustinov once remarked, Oedipus has long departed, but his complex remains. Achilles has left us his heel; Aphrodite, aphrodisiacs. 


\section{perifèria}

Number 6, June 2007

www.periferia.name

The history of the Balkans thus explains why no architectural style worthy of note can be traced between the ruins of the classical period and the characterless buildings of the last century. Palaces and other solid buildings arose, a few modern avenues and broad streets were constructed, but during the process the Balkan towns lost their pronounced architectural character. Even the smallest towns in European Turkey in which Muslims lived had public baths. When they left, the baths were no longer maintained or were even deliberately destroyed (Alexander 1827: 251; Johnson 1885: 21; Laveleye 1887: 97). Hammams, aqueducts and even fountains built by the Ottomans have vanished from Athens and Bucharest, Belgrade and Plovdiv, and everywhere else.

There was no place for the mosque and minaret in the new architecture, neither for any other tangible remainder of the Ottoman past. They were perceived as symbols of a bygone age, indeed as symbols of backwardness (see e.g. Pahor 1951: 126), as were all other Ottoman architectural features. Memory was literally obliterated, as monuments, mosques and other concrete manifestations of collective memory were erased, 'and mnemonic maps rewritten as normative maps for an ethnically reconfigured future' (Müller 2002: 16-7).

In the middle of the nineteenth century, the Balkans at last became 'Balkan,' looking like a copy or even a caricature of Western Europe. There was nothing original about the Balkan towns, nothing individual. Everything was borrowed. Instead of having their own identity the exteriors and interiors of dwellings, workshops and offices, and also the dress of the townspeople, followed fashions from Paris, Pest or Vienna. It was fashionable to look 'European' and this is what everyone tried to do. Townspeople affected a taste for modern art, modern music, the tango and the foxtrot, and ridiculed the songs and costumes of the peasants (Hornby 1863: 171-72; Black 1865: 499; Poole 1878: II, 53; Durham 1904: 280; Reed 1916: 52-3; Köhler 1930: 87). But Westerners saw them not as their equals but still as Eastern Other, though without their former charm: 'What a charming place Constantinople would be, were it a little less, or a great deal more, civilised! It is just too much European to be pleasant, and not enough so to make it perfection' (Jerningham 1873: 202). 


\section{perifèria}

Number 6, June 2007

www.periferia.name

However hard Easterners tried to look Western, travellers from the West often found them outlandish and ridiculous. At the beginning of the twentieth century an anecdote circulated in Western Europe about a young Romanian who boasted to his French friends that Bucharest was a little Paris, only to receive the immediate retort: 'Perhaps - but thank God Paris is not a large Bucaresti!' (Thornton 1937: 272).

The price of modernisation, that is 'Europeanisation,' was high: the history embodied in mosques, minarets, bazaars, hans, graveyards, bridges, homes and so on was destroyed as new ones, which substituted historic monuments with 'the ugliness of modernism' (Loti 1913: 63), were rapidly built instead. Losing their former appearance, the towns of the Balkans lost their spirit; losing their spirit, they lost their history. The image was new but hollow. In the Balkan towns there were practically no fine old buildings to be seen, for those built during the Ottoman occupation were destroyed and the modern ones were more or less 'economical imitations of French and British buildings' (Fox 1915: 158).

The Balkans was trying hard to be European and modern, and prove itself so to the world. Since Europe was seen as a foil to the Turks and as endowed with all conceivable positive attributes, the East was judged on its similarity to or difference from the West. To be less like Europe was to be Other, inferior, and to be more like Europe was to advance (Kabbani 1986: 6).

The change was vast, and the Balkans was 'Europeanised' - outwardly. As we have seen, the most radical changes were in urban architecture and fashion. This outward change might have been expected to bring about a complete Europeanisation of the Balkan people: once they and their towns had become outwardly indistinguishable from 'others in Europe,' it was supposed that they would acquire all the other qualities that had brought prosperity to the Western world - without, of course, adopting its vices. However, where food and coffee houses were concerned, the Ottoman legacy seemed to be much more tenacious. More strenuous efforts were made to de-Ottomanise in the ideological sphere (popular beliefs, customs, attitudes, value system). But, as a British expert on the 


\section{perifèria}

Number 6, June 2007

www.periferia.name

Balkans observed, a people cannot discard all its time-honoured habits at once:

Though it has been the Turk's for five hundred years, he has set no visible mark upon it. Roughly speaking, he has spent those five centuries in camping out on it temporarily as an army of occupation! Nothing is more surprising about him than the speed with which all visible signs of his existence can be wiped out, but the stain he has left upon the souls of the people is, alas! harder to erase (Durham 1904: 318).

Lattice windows were removed and the walls that surrounded houses in Balkan towns were demolished, but in domestic life new customs were adopted at a much slower pace. When Martin Gjurgjević visited an acquaintance, a Serbian merchant in Pristina, the host brought his young wife from the harem, unveiled, to kiss the visitor's hand, telling him that he had not done 'something like this before.' Apart from this woman, Gjurgjević saw no other unveiled in the town (Gjurgjević 1910: $55-6)$.

Ottoman domination - or tyranny - was social as well as political, and not only manners and morals but also social life were deeply affected by it. Nevertheless, it is a singular fact that no determined attempt was made to assimilate the Balkan peoples to the Ottoman way of life or to Islam during all those centuries of occupation: 'Mahomet did not abuse his victory. The religious tolerating spirit of the Turks was seen in his first act. He left to the Christians their churches and the liberty of public worship; he maintained the Greek patriarch in his office' (Lamartine 1847: II, 163).

The Ottomans did not try to assimilate their subject peoples, and in this respect they differed greatly from the contemporary governments of Western Europe. Where the Ottoman Empire followed a policy of non-interference, the European governments made every effort to extinguish the national spirit and the mothertongue of their subject peoples (Urquhart 1838: II, 236-37). In comparison, the attitude of the Sublime Porte towards the various creeds professed by its Christian subjects had 'ever been one of quite exceptional tolerance' (Garnett 1911: 141). 


\section{perifèria}

Number 6, June 2007

www.periferia.name

Notwithstanding its theocratic structure, the Ottoman Empire allowed the practice of any religion making the Balkans under its rule a vibrant example of multiculturalism: lands where 'all the nationalities of the world' carried on their normal lives as if 'immediately after the fall of the Tower of Babel.' It is well known that about 170,000 Jews were given asylum and granted freedom to practise their religion in Istanbul, Thessaloníki, Sarajevo and other Ottoman towns after they were expelled by the Spanish monarchs Ferdinand and Isabella in 1492 (see e.g. Nicolay 1568: 149; Dallaway 1797: 389; Noyes 1858: 504; Tozer 1869: I, 146; Chirol 1881: 9; Abbott 1903: 20; Brailsford 1906: 82; Garnett 1911: 38; Baker 1913: 194; Loti 1913: 60).

According to a seventeenth-century French author, in the whole Ottoman Empire, 'no places but Athens and Trebizond have preserved the privilege of excluding the Jews, though the Turkish officers have attempted several times to introduce them' (De la Guilletiere 1675: 152). It is less well known that there was once a large Trappist monastery, Marija Zvijezda, near Banja Luka. The monks had been expelled from France during the Revolution; they first took refuge in Germany but were driven out in 1868. As no Christian state was willing to take them in, they asked and received the sultan's permission to purchase land in the neighbourhood of Banja Luka and build their monastery there (Ruthner 1877: 20; Asboth 1890: 389; Renner 1897: 499; Thomson 1897: 167; Holbach 1908: 75; Trevor 1911: 29; Zavadil 1911: 3, 36; Šolta 1918: 26).

Even less known is the story of the Spanish Admiral Don Ferrante Gonzaga. He captured Hercegnovi in 1538 and built the chapel of St Anna there but the following year the Ottomans retook the town. They not only spared the chapel but gave permission in 1550 for the body of their old enemy Don Ferrante to be buried there beside his wife and son (Lyall 1930: 179).

In Sarajevo in the 1920s, Lester George Hornby witnessed a Bosnian peasant of the Orthodox faith dropping a coin into the begging-bowl of a blind Muslim squatting at the entrance to a mosque playing his gusle. Glancing at the peaceful little stalls where Muslims, Christians and Jews mingled at their work, each able to go his own way to cathedral, mosque or synagogue, he wondered 'if tolerance is not one of the 


\section{perifèria}

Number 6, June 2007

www.periferia.name

greatest of virtues' (Hornby 1927: 153). The rash of new buildings and the many lasting symbols of the Balkan people's break with their 'unspeakable past' did not signify their happy reunion with Europe but marked the end of a specific Balkan history. As Mrs Scott-Stevenson put it, the Eastern lands restored to Western civilisation lost their picturesque quality but kept their dirt and squalor (ScottStevenson 1883: 217). As soon as the Ottomans left, Europeanisation became the order of the day and the old Balkan spirit died. In the process, mythology replaced history; tolerance and multiculturalism were its first victims (see e.g. RihtmanAuguštin 2000: 193).

We have seen how vigorously the people of 'the mountainous peninsula' struggled to progress and how splendid were the results of their efforts to Europeanise. But in the process the quality that present-day Europe proudly claims as its foremost virtue was eliminated: tolerance of diversity. Travellers on our Balkan tour may in addition notice a curious fact: while the Balkans is now making every effort to be part of Europe as it once was, Europe now defines itself on the basis of its difference from the East, the Balkans included, and claims to be what the Balkans used to be for centuries.

\section{Bibliografía}

Abbott, George Frederick (1903). The Tale of a Tour in Macedonia. London: Edward Arnold.

Alexander, James Edward (1827). Travels from India to England. London: Parbury, Allen, and Co.

Angell, Norman (1912). Peace Theories and the Balkan War. London: Horace Marshall \& Son.

Arnold, Thomas (1838-43). History of Rome. London: B. Fellows; J. G. Rivington; J. Duncan; E. Hodgson; G. Lawford; J. M. Richardson; J. Boin; J. Bain; S. Hodgson; F. C. Westley; and L. A. Lewis. 


\title{
perifèria
}

\author{
Number 6, June 2007 \\ www.periferia.name
}

Asboth, Johann de (1890). An Official Tour through Bosnia and Herzegovina. London: Swan Sonnenschein.

Austell, Henry (1810). "The voyage of M. Henry Austell by Venice to Ragusa, and thence ouer-land to Constantinople: and from thence through Moldauia, Polonia, Silesia, and Germany into England, Anno 1586" en Hakluyt's Collection of the Early Voyages, Travels, and Discoveries of the English Nation II, pp. 318-39. London: R. H. Evans, J. Mackinlay, and R. Priestley.

Baker, B. Granville (1913). The Passing of the Turkish Empire in Europe. London: Seeley, Service \& Co.

Barlett, Ellis Ashmead (1897). The Battlefields of Thessaly. London: John Murray.

Barth, Heinrich (1864). Reise durch das Innere der Europäischen Türkei von Rustchuk über Philippopel, Rilo (Monastir), Bitolia und den Thessalischen Olymp nach Saloniki im Herbst 1862. Berlin: Verlag von Dietrich Reimer.

Black, Archibald Pollok (1865). A Hundred Days in the East. London: John F. Shaw. Boué, Ami (1840). Le Turquie d'Europe ou observations sur la géographie, la géologie, I'histoire naturelle, la statistique, les moeurs, les coutumes, l'archéologie, I'agriculture, l'industrie, le commerce, les governments divers, le clergé, I'histoire et l'état politique de cet empire. Paris: Arthus Bertrand.

Brailsford, Henry Noel (1906). Macedonia. London: Methuen \& Co.

Braun-Wiesbaden, Karl (1878). Reise-Eindrücke aus dem Südosten. Ungarn, Istrien, Montenegro, Griechenland, Türkei. Stuttgart: Aug. Berth. Auerbach.

Calvert, Frederick, Lord of Baltimore (1767). A Tour to the East, In the Years 1763 and 1764. With remarks on the City of Constantinople and the Turks. London: W. Richardson and S. Clark.

Chirol, M. Valentine (1881). 'Twixt Greek and Turk. Edinburgh and London: William Blackwood and Sons.

Clarke, Edward Daniel (1810-23). Travels in various countries of Europe, Asia and Africa. Cambridge: T. Cadell and W. Davies. 


\section{perifèria}

Number 6, June 2007

www.periferia.name

Cvijić, Jovan (1906). Nekolika promatranja o etnografiji makedonskih Slovena. Beograd.

Dallaway, James (1797). Constantinople Ancient and Modern. London: T. Cadell Jun. \& W. Davies.

De Windt, Harry (1907). Through Savage Europe. London: T. Fisher Unwin.

Douglas, J. A. (1919). The Redemption of Saint Sophia. A Historical \& Political Account of the Subject. London: The Faith Press.

Durham, Mary Edith (1904). Through the Lands of the Serb. London: Edward Arnold.

Durham, Mary Edith (1905). The Burden of the Balkans. London: Edward Arnold.

Edmonds, Paul (1927). The Land of the Eagle. London: George Rouledge \& Sons; New York: E. P. Dutton \& Co.

Eremiten von Gauting (1839). Reise nach dem Orient. Stuttgart: Hallberger'sche Verlagshandlung.

Fox, Frank (1915). The Balkan Peninsula. London: A. \& C. Black.

Garnett, Lucy M. J. (1911). Turkey of the Ottomans. London: Sir Isaac Pitman.

Gautier, Théophile. (1853). Constantinople. Paris: Michel Lévy Frère, LibrairesÉditeurs.

Gil'ferding, Aleksandr. (1859). Poězdka po Gercegovine, Bosnii i Staroj Serbii. St Petersburg: Zapiski imperatorskago russkago geografičeskago obščestva XIII.

Gjurgjević, Martin (1910). Memoari sa Balkana 1858-1878. Sarajevo.

Greg, William Rathbone (1833). Sketches in Greece and Turkey: with the Present Condition and Future Prospects of the Turkish Empire. London: James Ridgway.

Guilletiere, de la (1675). Athenes ancienne et novvelle. Et l'estat present de l'empire des Turcs, contenant la vie du Sultan Mahomet IV. Paris: Estienne Michallet. 


\section{perifèria}

Number 6, June 2007

www.periferia.name

Hahn, Johann Georg von. (1854). Albanische Studien. Jena: Verlag von Friedrich Mauke.

Hecquard, Hyacinthe (1858). Histoire et description de la Haute Albanie ou Guégarie. Paris: Chez Arthus Bertrand.

Holbach, Maude M. (1908). Dalmatia. The Land where East Meets West. London: John Lane The Bodley Head; New York: John Lane Company.

Hornby, Lady (1863). Constantinople during the Crimean War. London: Richard Bentley.

Hornby, Lester George (1927). Balkan Sketches. London: Brentano's.

Hugonnet, Léon (1886). La Turqie inconnue. Roumélie, Bulgarie, Macédoine, Albanie. Paris: L. Frinzine et Cie.

James, Lionel (1913). With the Conquered Turk. London: Thomas Nelson and Sons. Jeran, Luka (1872). Potovanje v Sveto Deželo, v Egipt, Fenicijo, Sirijo, na Libanon, $\checkmark$ Carigrad in druge kraje. Ljubljana: Založil pisatelj.

Jerningham, Hubert E. H. (1873). To and from Constantinople. London: Hurst and Blackett.

Johnson, E. E. (1885). On the Track of the Crescent. London: Hurst and Blackett.

Kabbani, Rana (1986). Europe's Myths of Orient. London: Macmillan.

Knighton, William (1854). European Turkey; Its People, Its Provinces, and Its History. London: John Cassell.

Köhler, Albert (1930). Sonne über dem Balkan. Dresden: Carl Reissner.

Kristeva, Julia (1991). Strangers to Ourselves. New York: Harvester Wheatsheaf.

A Lady. (1847). Wayfaring Sketches among the Greeks and Turks, and on the Shores of the Danube. London: Chapman and Hall.

Lamartine, Alphonse de (1847). Visit to the Holy Land: or, Recollections of the East. London: George Virtue. 


\section{perifèria}

Number 6, June 2007

www.periferia.name

Laveleye, Emile Louis Victor de (1887). The Balkan Peninsula. London: T. Fisher Unwin.

Leech, Harry Harewood (1869). Letters of a Sentimental Idler. New York: D. Appleton and Company.

Loti, Pierre (1913). Turkey in Agony. London: The Ottoman Committee.

Lyall, Archibald (1930). The Balkan Road. London: Methuen \& Co.

Morritt, John B. S. (1914). The Letters of John B. S. Morritt of Rokeby Descriptive of Journeys in Europe and Asia Minor in the Years 1794-1796. London: John Murray.

Müller, Joseph (1844). Albanien, Rumelien und die österreichisch-montenegrinische Gränze. Prag: Verlag von J. E. Calve'shen Buchhandlung.

Müller, Jan-Werner, ed. (2002). Memory and Power in Post-War Europe: Studies in the Presence of the Past. Cambridge: Cambridge University Press.

Neave, Dorina Lady (1949). Romance of the Bosporus. London: Hutchinson \& Co.

Nicolay de Dauphinoys, N. (1568). Les quatre premiers livres des navigations et peregrinations Orientales. Lyon: Gvillavme Roville.

Noyes, James O. (1858). Roumania. New York: Rudd \& Carleton.

Pahor, Jože (1951). Hodil po zemlji sem naši... Ljubljana: Mladinska knjiga.

Pardoe, Mrs. (1837). The City of the Sultan; and Domestic Manners of the Turks, in 1836. London: Henry Colburn.

Poole, Stanley Lane ed. (1878). The People of Turkey. London. John Murray.

Reed, John (1916). The War in Eastern Europe. London: Eveleigh Nash.

Renner, Heinrich (1897). Durch Bosnien und die Hercegovina kreuz und quer. Berlin: Dietrich Riemer.

Rihtman Auguštin, Dunja (2000). Ulice moga grada. Beograd: Biblioteka XX. vek.

Robinson, Vandeleur (1941). Albania's Road to Freedom. London: George Allen \& Unwin.Ruland, Bernd. Orient Expreß. Bayreuth: Hestia. 


\section{perifèria}

Number 6, June 2007

www.periferia.name

Ruthner, Francesco (1877). Un Viaggio a Maria Stella convento dei trappisti nella valle dell'Urbas presso Banjaluka in Bosnia colla descrizione della vita e delle opere dei poveri monaci di San Bernardo. Venezia: L. Merlo.

Sandys, George (1615). A relation of a iourney begvn Anno Dom. 1610. London: W. Barrett.

Scopetea, Ellie (1991). "Greek and Serbian enlightenment: a comparative approach", en Proceedings of the Fifth Greek-Serbian symposyum, pp. 201-9. Thessaloniki: Institute for Balkan Studies.

Scott-Stevenson, Esmé (1883). On Summer Seas. London: Chapman and Hall.

Šolta, Pawol (1918). Bosniski kraj a raj. Budyšin.

Spencer, Edmund (1851). Travels in European Turkey in 1850. London: Colburn and Co.

The Man Who Dined with Kaiser. (1916). My Secret Service. London: Herbert Jenkins.

Thomson, Harry Craufuird (1897). The Outgoing Turk. London: William Heinemann. Thornton, Philip (1937). Dead Puppets Dance. London: Collins.

Tozer, Henry Fanshawe (1869). Researches in the Highlands of Turkey. London: John Murray.

Trevor, Roy (1911). My Balkan Tour. London: John Lane The Bodley Head; New York: John Lane Company.

Upward, Allen (1908). The East End of Europe. London: John Murray.

Urquhart, David (1838). The Spirit of the East. London: Henry Colburn.

Villari, Luigi ed. (1905). The Balkan Question. London: John Murray.

Walker, Mary Adeleide (1897). Old Tracks and New Landmarks. London: Richard Bentley and Son. 


\section{perifèria}

Number 6, June 2007

www.periferia.name

Walsh, Robert (1836). A Residence at Constantinople, During a Period Including the Commencement, Progress, and Termination of the Greek and Turkish Revolutions. London: Frederick Westley and A. H. Davis.

Zavadil, Antonín (1911). Obrázky z Bosny. Praha: Josef Pelcl. 